\title{
An Innovation Management Class in a Polytechnic Environment
}

Dr. Thomas A Lacksonen, University of Wisconsin-Stout

\begin{abstract}
Innovation is a central driver of our country's economic prosperity. Industry sees innovation as the key to sustainable growth. Building on these ideas, a motto of the University of WisconsinStout is "Inspiring Innovation."

To support innovation on campus at UW-Stout, a one credit, on-line, self-paced course has been developed to teach innovation management basics to a wide variety of students. The only prerequisite is that the student comes to the course with a product idea, either from a class project or from extra-curricular ideas. In the course, students will learn intellectual property, market assessment, prototype development, and basic business plans. The class assignments relate these four topics to their product idea.
\end{abstract}

As part of the polytechnic focus of the university, students come from a wide variety of majors, including Engineering, Technology, Business, and Art and Design. Faculty and lab support from all of these areas are also available in all these disciplines.

One end result of the course is for students to decide to stop their product because in some way it is not commercially viable. This is not seen as a failure, but as a first-time learning experience. If a student wishes to pursue commercialization, one route is continued development at Stout through a variety of other class projects. Another route is direct commercialization to a manufacturer. Finally, continued development of larger and more innovative products could be supported through Manufacturing Extension Partners, the state of Wisconsin or other new business support organizations.

Future work is to expand and refine the routes forward by piloting the linkages with other classes and outside agencies. Successful products will be promoted to help grow the course enrollment.

\section{Introduction}

Innovation is finding a significantly new and better way of doing something or meeting a market need. It is the capacity and willingness to develop, organize and manage a business venture along with any of its risks in order to make a profit ${ }^{1}$. Peter Drucker defines innovation as the specific instrument of entrepreneurship, the act that endows resources with a new capacity to create wealth ${ }^{2}$. According to Michael Porter, innovation is a central issue in our country's economic prosperity ${ }^{2}$. Therefore, President Barack Obama in a state-of-the-union address asserted that we need to out-innovate the rest of the world ${ }^{3}$.

Invention is the design of a specific product. Entrepreneurship is the capacity and willingness to develop, organize and manage a business venture along with any of its risks in order to make a profit. The most obvious example of entrepreneurship is the starting of new businesses ${ }^{1}$. Innovation is the use of a new product, service, or method in business practice immediately 
subsequent to its discovery. There can be two types of innovation. Continuous or evolutionary innovations are brought about by many incremental advances in process or technology.

Discontinuous or revolutionary innovations are disruptive and new ${ }^{1}$. Innovation management connects innovation to entrepreneurship.

Industry sees innovation as the key to sustainable growth and productivity. Technological innovation is the most important driver of competitive success in many industries. Researchers and businesses with demonstrated knowledge of the innovation process and commercialization processes have a competitive advantage in creating jobs ${ }^{4}$. For example, $3 \mathrm{M}$ gets $34 \%$ of its revenue from products invented in the last 5 years, and plans to increase that number to $40 \%$ by $2017^{5}$.

In academics, engineering and technology schools have focused teaching and design experiences on invention. But recently, many have begun to include innovation management topics in the engineering and technology curriculum. For example, as part of its polytechnic mission, a motto of the University of Wisconsin-Stout is "Inspiring Innovation." A new course has been developed in innovation to meet the needs of a wide range of students.

\section{Existing programs}

Engineering and technology programs across the United States have begun to realize the importance of innovation and started offering academic elements of innovation in the programs.

Dartmouth University has the most audacious curriculum, as the Dartmouth Engineering Innovation program is an integrated program from undergraduate through doctoral degrees. There are a number of master's degrees that have innovation in their titles. Several MBA programs focus on innovation, including Boston University, Brown University, North Carolina State University, Rochester Institute of Technology, and the University of Texas-Austin. Art and Design programs on Innovation and Design include Carnegie Mellon University and Virginia Commonwealth University. Engineering programs in innovation are fewer, but include Carnegie Mellon University and Northwestern University. There are various levels of interaction between the business, design, and engineering colleges in these programs. But obviously, programs in different colleges have very different entrance and prerequisite requirements, making truly integrated programs difficult to achieve.

At the bachelor's level, there are fewer programs but more minors and courses. Clarkson University and University of Richmond are among the few universities to offer bachelor's degrees in innovation. Certificates in innovation are based on completion of a small number of courses and are usually available to both degree and no-degree seeking students. Such certificates can be obtained from schools such as Massachusetts Institute of Technology, Stanford University, University of Wisconsin-Madison, and University of Wisconsin-Stout. Minors are available to degree seeking undergraduate students, and are given at many universities from many different colleges. Similarly, there are many individual courses in innovation given at many universities from many different colleges. 


\section{Innovation Management course}

The focus of innovation management is to allow the organization to respond to an external or internal opportunity, and use its creative efforts to introduce new ideas, processes or products ${ }^{6}$. Many of our students will work for large corporations. The corporate aspect of innovation management is organizational development. Engineers are responsible for new product development but the corporation has separate departments and specialists for the commercialization efforts. Some of our students will develop their own products and companies. The commercialization aspect of innovation management is entrepreneurship. Here, the innovator may be an engineer and is responsible for all aspects of commercialization. The Stout course focuses on the commercialization aspect of innovation management.

Typically, innovation is taught in engineering, technology, and design programs. Topics include brainstorming, vetting, proof-of-concept, and pilot processes. Topics are taught via design process and design projects. Conversely, entrepreneurship is typically taught in business programs. Topics include strategy, marketing, finance, organizational development, and business plans. Topics are taught via management processes, case studies, and business plans.

To support the innovation emphasis at University of Wisconsin-Stout, an innovation management course has been developed to teach innovation and entrepreneurship basics to a wide variety of students. Key elements of the course:

- One credit. Because some programs do not have room for the course in their electives list at this time, the course is limited to one credit. This makes the course available to students who must take and pay for the course in addition to their regular course loads.

- On-line. Stout is a laptop campus with many on-line offerings available to students. The online option permits maximum scheduling flexibility for students. Since the projects are independent, there is little need for face-to-face lecturing.

- Self-paced. The course consists of 4 modules which the students can work on at any pace. So far, most students work to the deadlines rather than work ahead.

- Optional meetings. One optional class meeting demonstrated prototyping in the Fab Lab, which is partnered with MIT. A second optional class meeting was a pizza party to discuss and share ideas on their inventions and projects.

- Demographic. As part of the polytechnic focus of the university, students come from a wide variety of colleges, including the College of Science, Technology, Engineering and Math, College of Art and Design, and College of Management. The course is housed in the College of Management and taught by a faculty member with an engineering and new product development background.

- Prerequisite. The only prerequisite is that the students come to the course with a product idea. The idea can come from a class project or from extra-curricular ideas. Courses in which students generate new product ideas include Entrepreneurship, Mechanical Design, Manufacturing Systems Design, Industrial Design, and Apparel Design.

- Objective. By the end of the course the student will evaluate their product relative to these four topics and learn if and how to proceed with commercialization. The four topics are intellectual property, market analysis, prototype development, and basic business plans.

- Course materials. There is no specific textbook for the course. The bases of materials are on-line Innovation Management modules available through the University of Wisconsin 
System. Additional textbook chapters, trade journal articles, and videos supplement the online materials as necessary. Overall readings are 20 to 50 pages per module. Faculty and lab support from all of these areas are also available in all these disciplines.

- Project. The class assignments have the students write four 3-5 page papers, relating each of the four course topics to their product idea.

\section{Innovation management curriculum}

The innovation management course is divided into four modules, each with their own set of readings and assignment. Compared to other similar courses, there is an added module on prototyping but there is not a module on financial analysis. As part of Stout's "hands-on mindson" teaching emphasis, several open labs are available for both required coursework and elective projects such as these. Of prime usefulness, Stout's Fab Lab is designed specifically for creative, high-tech, and multi-disciplinary innovators for prototyping and custom production ${ }^{7}$. Conversely, no financial analysis and justification is required as part of the course. At this early stage of innovation, a broad-based overview is used to determine if a product has commercial potential. After this course, it is assumed that a student wishing to continue the product would do a more complete financial analysis in the near future.

A summary of the four modules is as follows:

1. Intellectual property. Students learn how to protect their ideas, including design journals and non-disclosure agreements. Students learn the different types of patents, copyrights, and trademarks. Recent America Invents Act changes to patent law are discussed. For the assignment, students describe initial steps they will take to protect their ideas and identify which type(s) of intellectual property applies to their product. Students do a brief patent search to see if their idea infringes on existing patents.

2. Market assessment. Students learn how to specifically define and analyze the market they are trying to reach. Students learn about marketing and sales channels to reach different types of markets. Competitors are identified and compared to their product. For the assignment, students identify the specific market for their product and its possible size. Possible sales and marketing channels for each market are identified. A basic benchmarking analysis versus competitors considers price, quality and functionality.

3. Prototyping. Students learn various types of prototypes, including analytical vs. physical prototypes and focused vs. comprehensive prototypes. Students learn an iterative design process. The Fab Lab demonstration occurs during this module. Uses of prototypes are discussed, including proof-of-concept, customer feedback, and preliminary sales. For the assignment, students determine which types of prototypes they have made or will make. Uses of the prototypes and the number of needed physical prototypes are identified.

4. Business plan. Students are taught the elements of a brief business plan. The problem or need is defined along with the product definition and how the product meets the need. A brief marketing and sales approach is identified. Financial needs are identified, although the complete budget and economic analysis are not required at this time. For the assignment, the student 
creates this brief business plan. For the conclusion, the student determines whether to continue or stop the project. If they continue, what are the next steps to commercialization?

One end result of the course is for students to decide to stop the product because in some way it does not appear to be commercially viable. Reasons to stop include possible patent infringement, small market size, strong market competition, technical shortcomings, or lack of required time and effort. This is not seen as a failure, but as a first-time learning experience. The course is a success if it prevents needless time and expense spent on a product that would not succeed. If a student wishes to move forward, development can continue on the student's own time and money, through a variety of other class projects at Stout, or through other governmental new business support organizations.

\section{Further campus projects}

Due to its polytechnic focus, UW-Stout has several classes that can do class projects related to the student products. In these situations, the Innovation Management class student is the client along with other companies with projects, and a class of fellow Stout students will assist in the project. However, student groups often select their projects, so the Innovation Management student must present and compete with other companies to get their project selected. Classes where assistance has been offered cross the 3 colleges, including:

- Marketing research. The class will develop detailed channel assessment, market analysis, and sales plans.

- Mechanical design. The class will create detailed prototypes and engineering drawings.

- Graphic design. The class will create a product logo and branding scheme.

- Entrepreneurship. The class will create a full business plan by expanding the brief business plan and completing a financial analysis.

- Manufacturing enterprise practicum. The class completes a pilot run of 100-200 units of the product, and while developing the production processes with tooling, and initial sales and marketing plans.

Beyond the campus, some government support is available. UW-Stout houses the Manufacturing Outreach Center ${ }^{8}$, a NIST Manufacturing Extension partner. The Outreach Center provides small business and entrepreneur support. The Outreach Center also has ties to the university Technology Park site, where small-scale production as an incubator company can be initiated. Fees are charged for these services, but are heavily subsidized for new businesses. The University of Wisconsin-System runs the WiSys Technology Foundation ${ }^{9}$, which pays for patenting of larger and more innovative product ideas, for a percentage of licensing agreements and profits.

\section{Initial offering results}

The Innovation Management course was initially offered in spring 2014 semester to 14 students. Included in the course were students from Business, Industrial Design, Apparel Design, Engineering Technology, and Manufacturing Engineering majors. Course evaluations were unanimously high with regards to both the topics covered and the structure of the course. Of the 14 projects, 10 wish to continue with their product commercialization, which is a bit high 
compared to other new product development ventures. With the variety of majors, the projects and future steps varied. A few examples are given below.

In-handle fishing net scale. The product was originally designed by a team in a Mechanical Design course for a specific company. Caught fish must be weighed to verify that they are legal size, and this product conveniently combines the net and scale into one product. The assignments uncovered a possible patent infringement problem, although the mechanism (digital vs. spring scale) is unique. Since the product was sponsored by an existing company, the company was told of the patent infringement concern, but still hopes to market and sell the idea. A picture of the product is in Figure 1.

Bar top leveler. The product allows a plate of food to be served on a level surface above an uneven bar lip, placing the food close to the customer. This semester, the Manufacturing Enterprise Practicum class will complete final design, production tooling, production process, pilot production, and initial sales plan. The goal is to continue to manufacture and sell the product as a side business. A picture of the student pitching the idea to the class is shown in Figure 2.

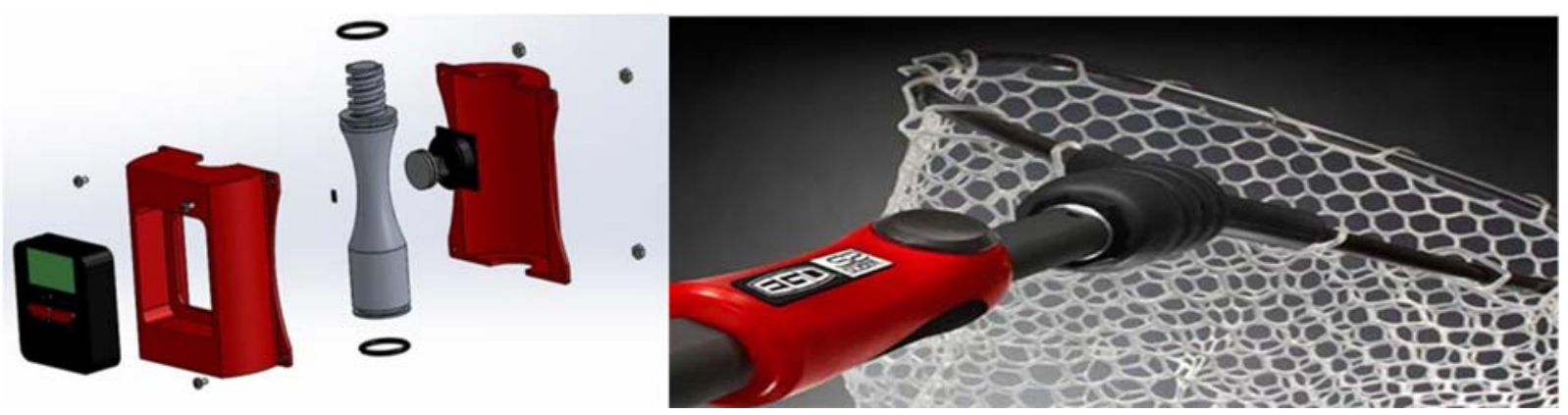

Figure 1 - Sample product - fishing net scale

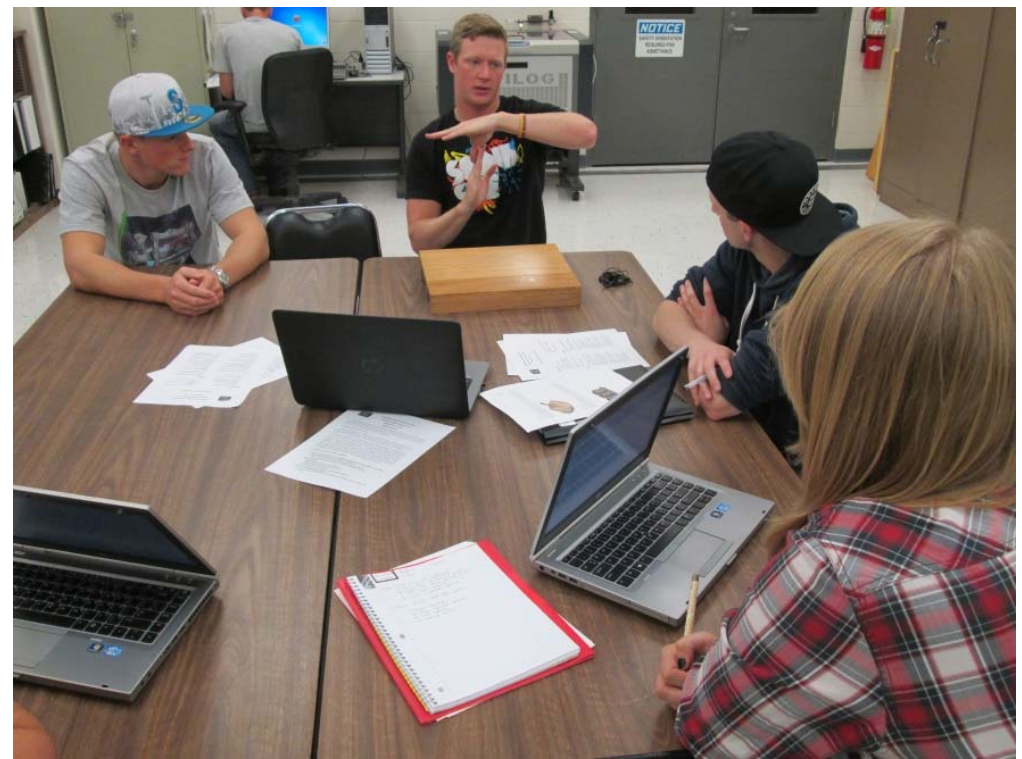

Figure 2 - Sample class interaction, presenting the bar top leveler to practicum class students 
Cross-bow stabilizer. The product reduces flexing of a cross-bow, allowing for straighter shots. This semester a Market Research class will provide a competitor analysis, create an brand name and logo, and identify distribution channels. The student will complete and test a working prototype to verify the design claims. The long-term goal is to sell the idea to an existing cross-bow company.

\section{Conclusion}

Innovation is critical to our country's future economic prosperity. Our engineering and technology students benefit from an understanding of the innovation management process, particularly if they have an entrepreneurial bent. Therefore, University of Wisconsin-Stout created an elective Innovation Management course for these students. The course covers intellectual property, market assessment, prototyping, and business plan topics. An initial offering of the course in Spring 2014 was a success based on student feedback and the number of products students are continuing to develop. The course will be offered once per semester starting in Fall 2014.

As part of the polytechnic focus, the new products will be linked with other Stout classes for further development. It is hoped that this synergy will inspire other students to develop new products and take the Innovation Management course. Given the number of student ideas generated in existing courses at Stout each year, the goal is to have over 100 students per year in this course.

Marketing efforts in both design and support classes are being used to get the word out about the Innovation Management course. Additionally, there is hope for a large "success story" that captures the essence of the course and that can be distributed through a variety of media channels.

\section{Bibliography}

1. Web Finance (2014) www.businessdictionary.com.

2. Brainy Quote (2014) www.brainyquote.com.

3. CNN (2011) www.cnn.com/2011/POLITICS/01/25/state.of.the.union/.

4. Schilling, M.A. (2010) Strategic Management of Technological Innovations (3rd ed.). New York, NY: McGraw-Hill Irwin.

5. CNBC (2013) 3M CEO: Research Is 'Driving This Company'. http://www.cnbc.com/id/100801531\#.

6. Kelly, P., Kranzburg, M. (1978) Technological Innovation: A Critical Review of Current Knowledge. San Francisco, CA: San Francisco Press.

7. UW-Stout (2014) www.uwstout.edu/discoverycenter/fablab.cfm.

8. UW-Stout (2014) www.uwstout.edu/moc/.

9. UW-System (2014) www.wisys.org. 